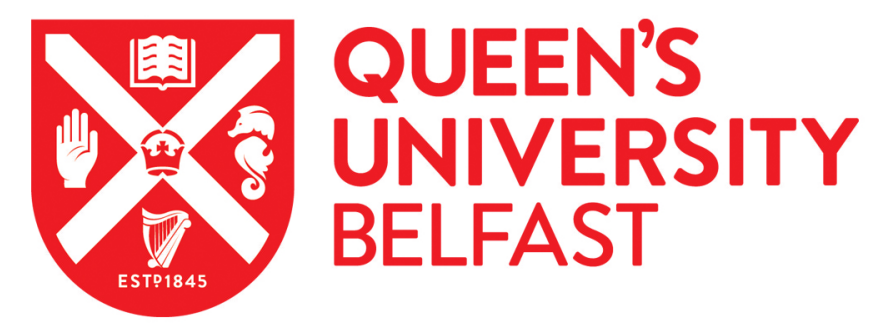

\title{
Establishment of monoxenic culture between the arbuscular mycorrhizal fungus Glomus sinuosum and Ri T-DNA-transformed carrot roots
}

Bi, Y. L., Li, X. L., Wang, H. G., \& Christie, P. (2004). Establishment of monoxenic culture between the arbuscular mycorrhizal fungus Glomus sinuosum and Ri T-DNA-transformed carrot roots. Plant and Soil, 261(12), 239-244. https://doi.org/10.1023/B:PLSO.0000035537.16639.7b

Published in:

Plant and Soil

Queen's University Belfast - Research Portal:

Link to publication record in Queen's University Belfast Research Portal

\section{General rights}

Copyright for the publications made accessible via the Queen's University Belfast Research Portal is retained by the author(s) and / or other copyright owners and it is a condition of accessing these publications that users recognise and abide by the legal requirements associated with these rights.

\section{Take down policy}

The Research Portal is Queen's institutional repository that provides access to Queen's research output. Every effort has been made to ensure that content in the Research Portal does not infringe any person's rights, or applicable UK laws. If you discover content in the Research Portal that you believe breaches copyright or violates any law, please contact openaccess@qub.ac.uk. 


\title{
Establishment of monoxenic culture between the arbuscular mycorrhizal fungus Glomus sinuosum and Ri T-DNA-transformed carrot roots
}

\author{
Yinli $\mathrm{Bi}^{1,2}$, Xiaolin $\mathrm{Li}^{1,4}$, Honggang Wang ${ }^{1}$ \& Peter Christie ${ }^{1,3}$ \\ ${ }^{1}$ Key Laboratory of Plant Nutrition, Ministry of Agriculture; Key Laboratory of Plant-Soil Interactions, Ministry \\ of Education; and Department of Plant Nutrition, College of Agricultural Resources and Environmental Sciences, \\ China Agricultural University, Beijing 100094, China. ${ }^{2}$ Department of Resource Development, China University \\ of Mining and Technology, Beijing 100083, China. ${ }^{3}$ Agricultural and Environmental Science Department, Queen's \\ University Belfast, Newforge Lane, Belfast BT9 5PX, UK. ${ }^{4}$ Corresponding author*
}

Received 26 November 2002. Accepted in revised form 15 May 2003

Key words: arbuscular mycorrhiza, Glomus sinuosum, monoxenic culture, Sclerocystis sinuosa, sporocarps, transformed carrot roots

\begin{abstract}
We report for the first time the establishment of an arbuscular mycorrhizal association between Glomus sinuosum (= Sclerocystis sinuosa) and transformed Ri T-DNA carrot (Daucus carota L.) roots in monoxenic culture. The G. sinuosum sporocarps survived not as single spores, but as sporocarps in the environment. The mode of germination of $G$. sinuosum was by extension of hyphae around the sporocarp. Numerous vegetative spores, arbuscules and vesicles were produced after the roots were infected by the hyphae. New mature sporocarps started to form after four months in the culture system. Forty-seven sporocarps were produced on average in each culture dish after six months, and these newly produced sporocarps were capable of germination in the growth medium.
\end{abstract}

\section{Introduction}

Numerous studies have demonstrated the beneficial role of arbuscular mycorrhizal (AM) fungi in improving plant growth by increasing resistance to drought and disease or by enhancing the efficiency of nutrient absorption (Smith and Read, 1997). Although axenic cultures of these fungi cannot be established, it is possible to grow AM fungi in sterile conditions in root-organ culture (Fortin et al., 2002).

An increasing number of AM fungal species have been cultured monoxenically as described in a number of papers reporting the production of root-organ cultures. These include Acaulospora rehmii (Dalpé and Declerck, 2002), Gigaspora rosea (Bago et al., 1998), Gigaspora margarita (Diop et al., 1992; MillerWideman and Watrud, 1984), Gigaspora gigantea (Gadkar et al., 1997), Glomus etunicatum (Schreiner and Koide, 1993), Glomus intraradices (Chabot et

\footnotetext{
* FAX No: +86 10 62891016. E-mail: lix1@cau.edu.cn
}

al., 1992; St-Arnaud et al., 1996), Glomus versiforme (Declerck et al., 1996; Diop et al., 1994), Glomus caledonium (Karandashov et al., 2000), Glomus fasciculatum and Glomus macrocarpum (Declerck et al., 1998), Glomus proliferum (Declerck et al., 2000), Glomus deserticola (Mathur and Vyas, 1995) and Glomus fistulosum (Gryndler et al., 1998). Glomus sinuosa (Gerdemann and Bakshi) Almeida and Schenck, formerly named Sclerocystis sinuosa (Gerdemann and Bakshi), produces complex sporocarps that have recently been proposed as an advanced character of some Glomus species (Redecker et al., 2000). Gerdemann and Bakshi (1976), Wang et al. (1992) and $\mathrm{Wu}(1993 \mathrm{a}, \mathrm{b})$ provided limited information on some of the morphological characteristics, including the size, colour and shape of the sporocarps and the arrangement of spores inside the sporocarps. Successful monoxenic culture of $G$. sinuosum would certainly help increase our knowledge of this AM fungus and would represent a powerful tool for taxonomic investigations. The present study reports for the first time the 
cultivation of $G$. sinuosum on Ri T-DNA transformed carrot roots with sporocarps and describes some of the morphological characteristics of the cultures.

\section{Materials and methods}

\section{Fungal inoculum}

The AM fungus used was Glomus sinuosum (Gerdemann and Bakshi) Almeida and Schenck, originally recovered from soil collected in Guiling, Guangxi province, China by Wang et al. (1992) and maintained in pot culture on red clover (Trifolium pratense L.) at the Institute of Soils and Fertilizers, Chinese Academy of Agricultural Sciences, Beijing. The fungus was propagated in pot culture by inoculation with single sporocarps in black PVC tubes. Sporocarps were extracted by wet sieving and surface sterilized by treatment with $2 \%$ Chloramine T plus two drops of Tween 20 for $15 \mathrm{~min}$, then soaking in an antibiotic solution containing $200 \mathrm{mg} \mathrm{L}^{-1}$ streptomycin sulphate and $100 \mathrm{mg} \mathrm{L}^{-1}$ gentamycin sulphate for $15 \mathrm{~min}$ and rinsing 3-5 times with sterile water. The sporocarps were then placed in one half of Petri dishes (10 sporocarps per dish) containing $0.8 \%$ Bacto-Agar medium. The dishes were incubated at $27^{\circ} \mathrm{C}$ in a constant temperature box to promote germination. Streptomyces orientalis (an unspecified strain purchased from the Institute of Microbiology, Chinese Academy of Sciences) was added to the medium in the other half of each Petri dish to speed up sporocarp germination (Mugnier and Mosse, 1987). The helper bacterium remained physically separate from the sporocarps throughout the procedure. The germinated sporocarps were then transferred axenically into the experimental dishes containing M medium using a sterile 7-mm cork borer and cultured with transformed Ri T-DNA carrot roots.

\section{Source of root organ culture}

Transformed Ri T-DNA carrot roots (Daucus carota cv. Takii) were obtained. They were routinely cultivated on a minimal medium (M medium) by the method of Bécard and Fortin (1988).

\section{Experimental culture}

The experiments were conducted by placing a single germinating sporocarp with a single transformed root in the same Petri dish and incubating at $27^{\circ} \mathrm{C}$ in the dark. Every two days the dishes were checked for formation of a plant-fungus association. After two months some of the roots were examined for mycorrhizal colonization by clearing and staining with trypan blue using the method of Phillips and Hayman (1970). The cultures were maintained for a further four months to observe the establishment of the symbiotic association and the formation of new sporocarps. All the dishes were kept inverted during the period of culture to compensate for the negative geotropism of the transformed roots.

\section{Results}

\section{Structure of the sporocarps}

This fungus has a very characteristic pattern of sporocarp formation (Figure 1), as described by Wang et al. (1992) and corresponding closely to the description by Gerdemann and Bakshi (1976). The sporocarps are globose to subglobose and brownish-black to black, with a diameter of 260-330 $\mu \mathrm{m}$. The fruiting body of each sporocarp is composed of chlamydospores whose lateral walls adhere to one another. The connecting hyphae are embedded in a central hyphal plexus. Chlamydospores are formed radially in a single, tightly packed layer around a central plexus of hyphae. Chlamydospores are yellow-brown to brown, obovoid to ellipsoid, and with a wall thickness of about $2.8-8.5 \mu \mathrm{m}$. The base is composed of sterile hyphae. Mature sporocarps have a peridium up to 13.5-25.0 $\mu \mathrm{m}$ thick which is composed of hyphae of 2-3 $\mu \mathrm{m}$ wall thickness and 6.0-7.5 $\mu \mathrm{m}$ diameter. They are visible to the naked eye.

\section{Sporocarp germination and hyphal growth}

Germination of sporocarps of $G$. sinuosum occurs by extension of hyphae around the sporocarp from different directions. Some sporocarps can produce 6-7 germ tubes (Figure 2). In contrast with the germination of Gigaspora margarita (Bi et al., 1999), each chlamydospore can be considered as a germinating body and this may increase the probability of contact with the host plant roots.

Infection of transformed Ri T-DNA carrot roots by G. sinuosum The roots were excised, placed in a Petri dish and stained. Entry points were readily observed (Figure 5), together with vesicles (Figure 6) and arbuscules in the root cells (Figure 7). This is a new 

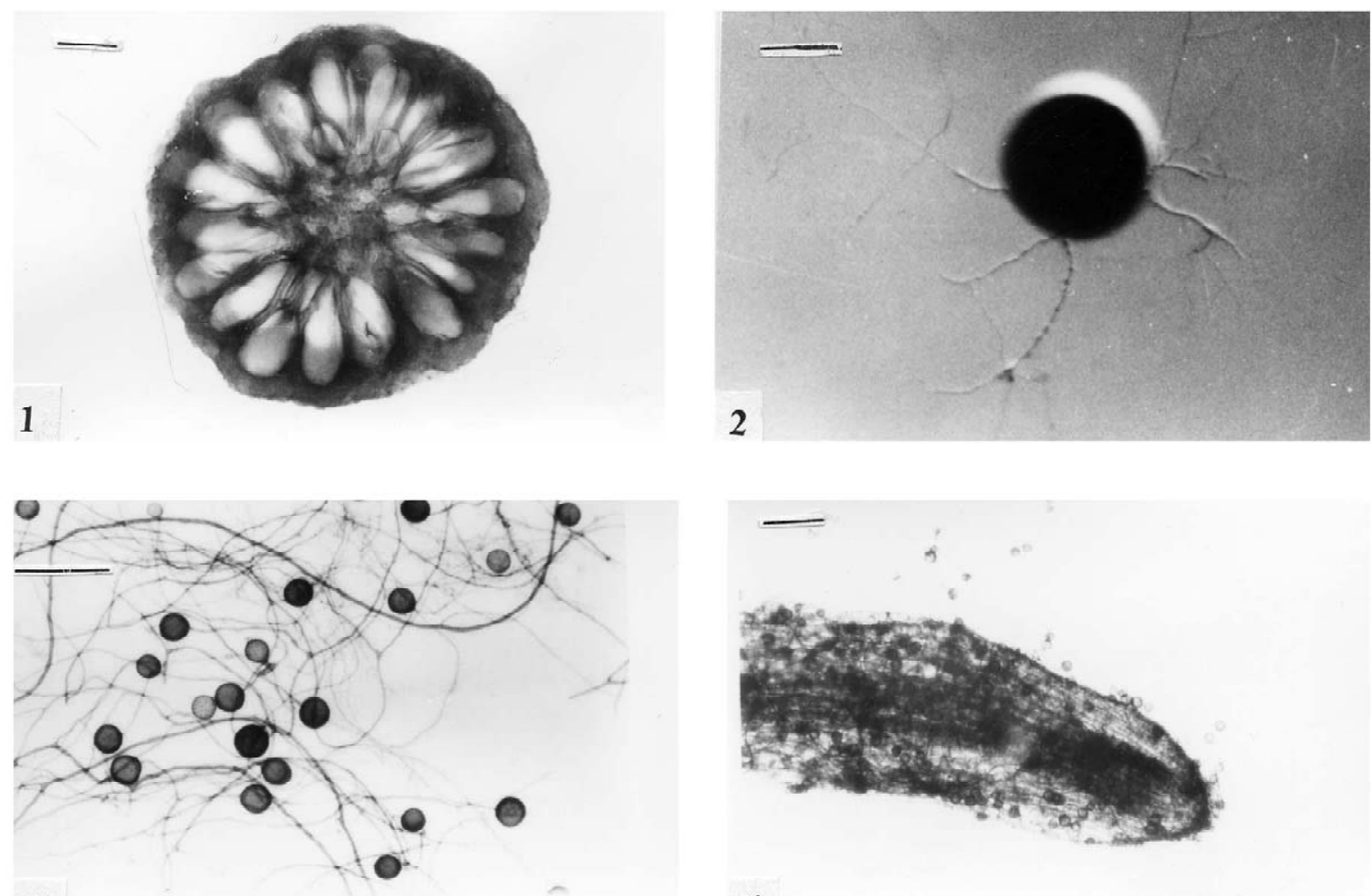

3

4
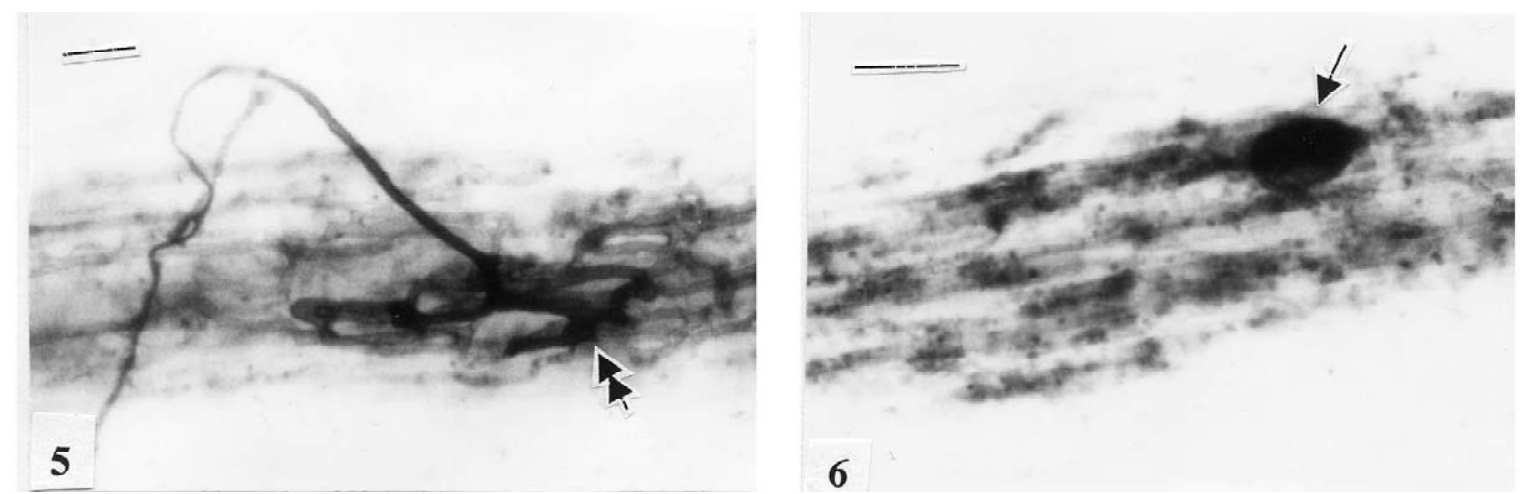

Figures 1-6. Sporocarp of Glomus sinuosum; bar $50 \mu \mathrm{m}$. (2) Germination of G. sinuosum sporocarp; bar $200 \mu \mathrm{m}$. (3) Formation of vegetative spores of G. sinuosum; bar $60 \mu \mathrm{m}$. (4) Root infection by G. sinuosum hyphae and numerous vegetative spores; bar $120 \mu \mathrm{m}$. (5) G. sinuosum hyphae infecting a root (arrow); bar $100 \mu \mathrm{m}$. (6) A vesicle of $G$. sinuosum (arrow); bar $40 \mu \mathrm{m}$.

demonstration of the use of these sporocarps for the establishment of monoxenic culture.

\section{Formation of vegetative spores of $\mathrm{G}$. sinuosum}

After two months it was observed that the hyphae had grown extensively with much branching. The direction of branching was almost perpendicular to the thick-walled hyphae. We observed numerous vegetative spores of $G$. sinuosum that were produced in the medium (Figure 3 ). They were globose to subglobose, and were $24 \mu \mathrm{m}$ in diameter on average (range 15-30 $\mu \mathrm{m}$ ). We observed numerous inclusions resembling oil droplets in the vegetative spores under the microscope. As the spores matured they changed from a light colour to a dark colour. Hyphae encircled 

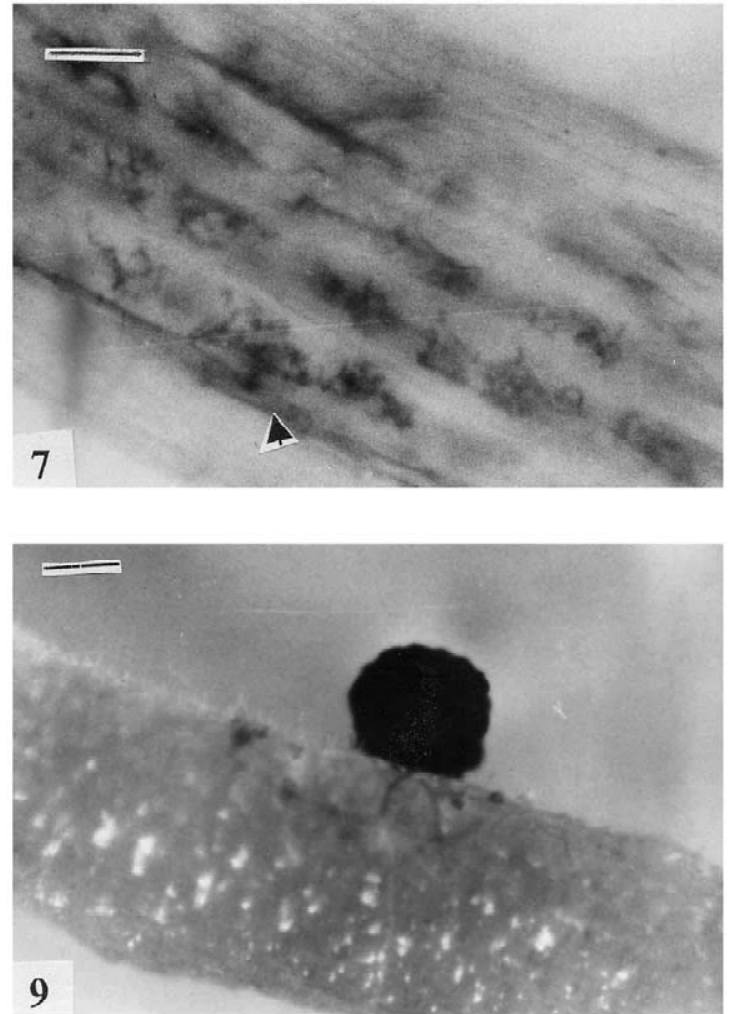
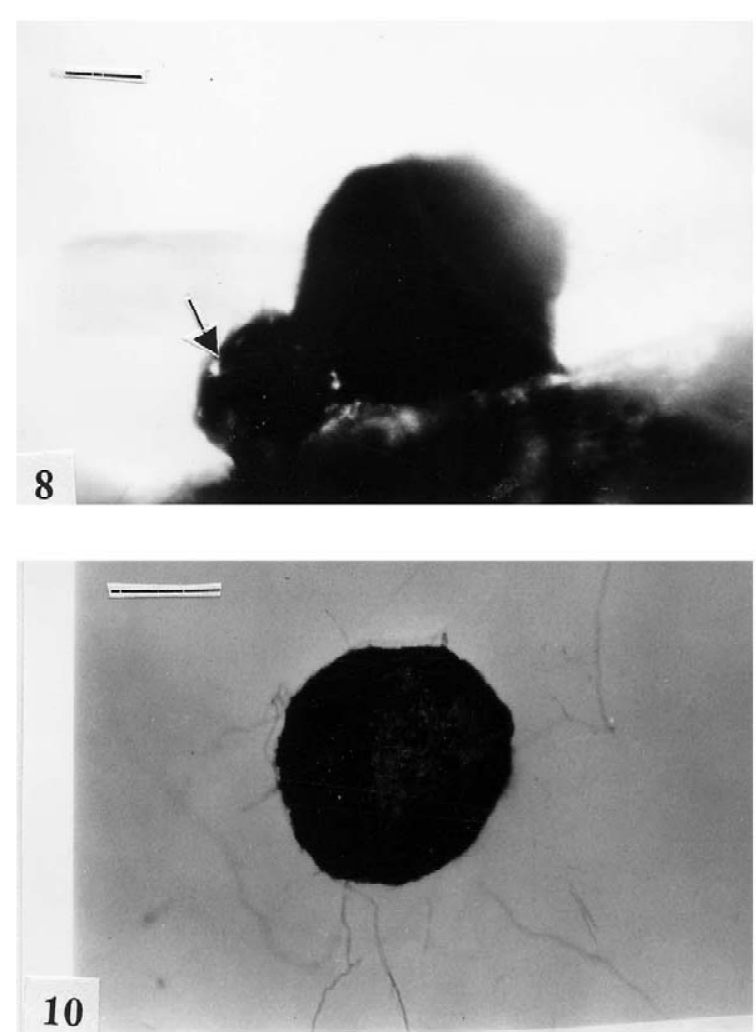

Figures 7-10. Arbuscles of G. sinuosum (arrow); bar $100 \mu \mathrm{m}$. (8) Formation of new sporocarps showing no peridium (arrow); bar 100 $\mu \mathrm{m}$. (9) Formation of a mature sporocarp; bar $135 \mu \mathrm{m}$. (10) Germination of a new sporocarp of G. sinuosum; bar $100 \mu \mathrm{m}$.

the roots, formed many vegetative spores (Figure 4) and grew very prolifically. Hyphae started to infect the fine roots in the medium, thus producing an extensive hyphal network and forming a mycorrhizal association.

\section{Formation of new sporocarps}

After culture of the symbiosis for four months, we found that the symbiosis produced numerous vegetative spores. After culture for six months, about 47 mature sporocarps were produced on average in each Petri dish. When young sporocarps formed, the peridium was virtually absent (Figure 8 ), with an average diameter of only $128 \mu \mathrm{m}$ (range $67-155 \mu \mathrm{m}$ ). As the sporocarps matured, their size increased and the diameter of the peridium reached $272 \mu \mathrm{m}$ on average with a range of 207-363 $\mu \mathrm{m}$ (Figure 9). The mature sporocarps had the same appearance as the mother sporocarps.

\section{Germination of the newly matured sporocarps}

In order to check the germination ability of the newly formed sporocarps, we transferred some of them axenically onto $0.8 \%$ Bacto-Agar medium. After culture for one week, new hyphae had extended from the sporocarps (Figure 10) and the hyphae were still capable of colonizing the roots.

\section{Discussion}

Monoxenic culture technology is a very powerful tool for the experimental establishment of arbuscular mycorrhizal associations. A small but growing number of papers have reported the successful establishment of AM associations using a number of AM fungal species (Fortin et al., 2002). Our experiment has added $G$. sinuosum to the list of fungi by using monoxenic culture with transformed Ri T-DNA carrot roots.

Different AM fungal species have different modes of germination. The G. sinuosum sporocarp is com- 
posed of many chlamydospores. In theory, each chlamydospore within a sporocarp has the potential to germinate, and in contrast with the spores of other species, for example Gigaspora margarita and Glomus intraradices (Bi et al., 1999, 2000), their spore germination consists of the extension of only one germ tube with subsequent branching, a germination pattern that may increase the probability of root infection. Hyphal branching is prolific and $G$. sinuosum may therefore be an excellent choice of fungal species to select for studies on the extramatrical hyphae and the hyphosphere.

Mycorrhizal association was established after the formation of arbuscular and vesicular structures and hyphal coiling in the root cells. Taken together, all of these characteristics indicated the successful establishment of a mycorrhizal association. Numerous vegetative spores were then produced. These were about $24 \mu \mathrm{m}$ in diameter, with somewhat variable shape. These spores may possess similar levels of survival and propagation potential to those of mature spores (Dalpé and Declerck, 2002). The production of large numbers of mature sporocarps in monoxenic culture may provide a good supply of experimental material for genetic and physiological studies on the mycorrhizal association and suggests that $G$. sinuosum can complete its life cycle in the monoxenic culture system in vitro. Vesicles were also observed in the monoxenic cultures and more detailed investigation is required on the vesicles of $G$. sinuosum.

\section{Acknowledgements}

We thank the National Science Foundation of China (Project 3023250 and 40201051) for generous financial support and two anonymous referees for their helpful comments on the manuscript.

\section{References}

Bécard G and Fortin J A 1988 Early events of vesicular-arbuscular mycorrhiza formation on Ri T-DNA transformed roots. New Phytol. 108, 211-218.

Bi Y L, Wang H G and Li X L 1999 The morphological characteristics of AM symbiosis between an arbuscular mycorrhizal fungus and transformed Ri T-DNA carrot roots. Mycosystema 18, 164-167.

Bi Y L, Wang H G and Li X L 2000 Establishment of dual culture for arbuscular mycorrhiza and formation of hyphosphere. Mycosystema. 19, 517-521.

Chabot S, Bécard G and Piché Y 1992 Life cycle of Glomus intraradix in root-organ culture. Mycologia 84, 315-321.
Dalpé Y and Declerck S 2002 Development of Acaulospora rehmii spore and hyphal swellings under root-organ culture. Mycologia 94, 850-855.

Declerck S, Cranenbrouck S, Dalpé Y, Seguin S, GrandmouginFerjani A, Fortaine J and Sancholle M 2000 Glomus proliferum sp. nov.: a description based on morphological, biochemical, molecular and monoxenic cultivation data. Mycologia 92, 11781187.

Declerck S, Strullu D G and Plenchette C 1996 In vitro massproduction of the arbuscular mycorrhizal fungus, Glomus versiforme, associated with $\mathrm{Ri}$ T-DNA transformed carrot roots. Mycol. Res. 100, 1237-1242.

Declerck S, Strullu D G and Plenchette C 1998 Monoxenic culture of the intraradical forms of Glomus sp. isolated from a tropical ecosystem: a proposed methodology for germplasm collection. Mycologia 90, 579-585.

Diop T A, Bécard G and Piché Y 1992 Long-term in vitro culture of an endomycorrhizal fungus, Gigaspora margarita, on Ri T-DNA transformed roots of carrot. Symbiosis 12, 249-259.

Diop T A, Plenchette C and Strullu D G 1994 Monoxenic axenic culture of sheared-root inocula of vesicular-arbuscular mycorrhizal fungi associated with tomato roots. Mycorrhiza 5, 17-22.

Fortin J A, Bécard G, Declerck S, Dalpé Y, St Arnaud M, Coughlan A P and Piché Y 2002 Arbuscular mycorrhiza on root organ cultures. Can. J. Bot. 80, 1-20.

Gadkar V, Adholeya A and Satyanarayana T 1997 Randomly amplified polymorphic DNA using the M13 core sequence of the vesicular-arbuscular mycorrhizal fungi Gigaspora margarita and Gigaspora gigantean. Can. J. Microbiol. 43, 795-798.

Gerdemann J W and Bakshi B K 1976 Endogonaceae of India: two new species. Trans. Br. Mycol. Soc. 66, 340-343.

Gryndler M, Hrselova H, Chvatalova I and Vosátka M 1998 In vitro proliferation of Glomus fistulosum intraradical hyphae from mycorrhizal root segments of maize. Mycol. Res. 102, 1067-1073.

Karandashov V, Kuzovkina I, Hawkins H and George E 2000 Growth and sporulation of the arbuscular mycorrhizal fungus Glomus caledonium in monoxenic culture with transformed carrot roots. Mycorrhiza 10, 23-28.

Mathur N and Vyas A 1995 In vitro production of Glomus deserticola in association with Ziziphus nummularia. Plant Cell Rep. 14, 735-737.

Miller-Wideman M A and Watrud L S 1984 Sporulation of Gigaspora margarita on root cultures of tomato. Can. J. Microbiol. 30, 642-646.

Mugnier J and Mosse B 1987 Spore germination and viability of a vesicular-arbuscular mycorrhizal fungus, Glomus mosseae. Trans. Br. Mycol. Soc. 88, 411-413.

Phillips J M and Hayman D S 1970 Improved procedures for clearing roots and staining parasitic and VA mycorrhizal fungi for rapid assessment of infection. Trans. Br. Mycol. Soc. 55, $158-160$.

Redecker D, Morton J B and Bruns T D 2000 Molecular phylogeny of the arbuscular mycorrhizal fungi Glomus sinuosum and Sclerocystis coremioides. Mycologia 92, 282-285.

Schreiner R P and Koide R T 1993 Stimulation of vesiculararbuscular mycorrhizal fungi by mycotrophic and nonmycotrophic plant root systems. Appl. Environ. Microbiol. 59, 27502752.

Smith S E and Read D J 1997 Mycorrhizal Symbiosis. 2nd ed. Academic Press, London.

St-Arnaud M, Hamel C, Vimard B, Caron M and Fortin J A 1996 Enhanced hyphal growth and spore production of the arbuscular mycorrhizal fungus Glomus intraradices in an in vitro system in the absence of host roots. Mycol. Res. 100, 328-332. 
Wang H G, Wu G Y and Li H Q 1992 Discovery of a new record species Glomus sinuosum on Endogonaceae in China. Acta Mycologica Sinica 11, 78-79 (in Chinese).

Wu C G 1993a Glomales of Taiwan: III. A comparative study of spore ontogeny in Sclerocystis (Glomaceae, Glomales). Mycotaxon 47, 25-39.

Wu C G 1993b Glomales of Taiwan: IV. A monograph of Sclerocystis (Glomaceae). Mycotaxon 47, 327-349. 